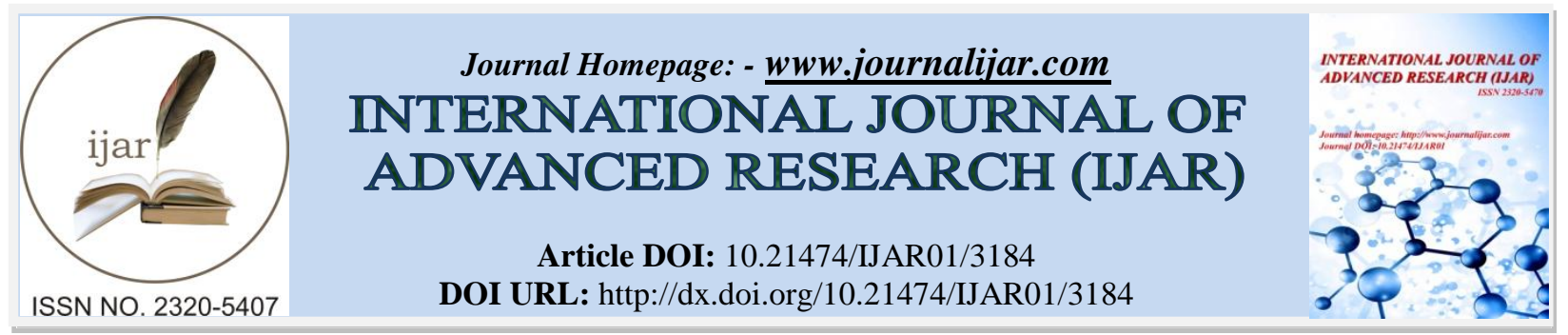

RESEARCH ARTICLE

\title{
FACTORS OF QUALITY STANDARDS IN THE TEACHING PROCESS IN HIGHER EDUCATION INSTITUTIONS AND ITS IMPACT ON THE STUDENTS SATISFACTION: A CASE STUDY OF A PRIVATE UNIVERSITY IN DUBAI
}

Maysoon Alkaisi.

\section{Manuscript Info}

Manuscript History

Received: 10 December 2016

Final Accepted: 18 January 2017

Published: February 2017

Key words:-

Higher Educational institutes, service quality standards, student satisfaction, United Arab Emirates.

\begin{abstract}
The United Arab Emirates is becoming a hub for quality in teaching in the higher education institutions. There are two types of these institutions, such as those which are under the private programs and the ones which are under the government programs. A private university in Dubai is going to be taken as a case study for its reputation as one of the centres of excellence in higher education in the region. This study examines the quality standards in the teaching process in higher education institutions and its impact on the student satisfaction in private institution of Dubai. The questionnaires used to collect quantitative information. The questionnaires were distributed to 50 male and female students of Private Universities in Dubai aged between 20 to 40 years and the Statistical Package for Social Sciences was used for data analysis. The study found that students at Private Universities in Dubai have high satisfaction levels because the institution offers courses that impact on the students with right skills and knowledge. However, the university's IT infrastructure underdeveloped hence the need to invest more resources in upgrading the system. By doing so, the institution will attract students from the region and other parts of the world.

The study recommends policy to enhance high quality standards in the Teaching Process in Higher Education Institutions such that managers and administrative executives should consider enhancing the academic and institutional status the University with regard to the highlighted determinants of teaching quality education as well as the different student dimensions of quality.
\end{abstract}

Copy Right, IJAR, 2017,. All rights reserved.

\section{Introduction:-}

The growth of the United Arab Emirates higher education sector has improved in the last two decades and became one of the highest international institutions of higher education in the world. Since the 1960s, the United Arab Emirates is rated among the world's rapidly developing and wealthiest countries in the world.

As the establishment of the first university in the region in 1977, education in these institutions was in English (Witte, 2015). For that reason, students in these education institutions study both English and classical Arabic languages which leads to many challenges for teachers to teach complex content. Moreover, many students graduate from public high schools do not advance their education. To motivate such students, most institutions offer 
foundation programs for students entering these institutions to enhance their competencies in core subjects such as math, English, Arabic, and IT before starting their academic studies (Witte, 2015).

Recent studies believe that the quality of education in higher education institutions in the United Arab Emirates has improved in the past few years following the federal Ministry of Higher Education involvement through improving the education quality standards. And today, there are more than 70 private institutions of higher education in the United Arab Emirates licensed by related government agencies such as the Ministry of Higher Education and hence an increase in the numbers of enrolled learners from 52,926 students to 128,279 (Witte, 2015). This research tries to establish the efforts of a private university in Dubai towards providing quality in teaching and its impact on the students' satisfaction.

\section{Literature Review:-}

Higher education in the Arab world has experienced a number of major developments such as the expansion of previously established universities, increased numbers of students, public and private sector enthusiasm for investing in higher education, and the emergence of new disciplines and styles of learning. By noting these developments, sector leaders have recognized a need to support the application of quality standards in higher education to ensure the quality and final outputs of universities (Bashour, 2005).The sustainability of these countries owned private institution in Dubai against the public owner universities is as results of their service qualities which meet up with expectation of the residences in Dubai. Rendering the expected value in competitive business environment in concentration of quality of service is an important element for business success, and experts concur that the most powerful competitive tool currently reshaping marketing and business strategy is service quality (Eraghi\&Atharinejad, 2012).

\section{Student satisfaction:-}

Owston, York \& Murtha (2013) define student satisfaction as the desirous outcome of a job or task striving to meet the individual's esteem. Student satisfaction from teaching quality education at the universities plays an integral part in determining the accuracy and originality of the system. In this case, the satisfaction of the students denotes the level of grooming their mentality, course knowledge, and skill development. Students' satisfaction from teaching quality education is, therefore, the resultant outcome of the University's educational and administrative coherent performance of the system.

Moreover, the institutions that facilitate UAE's learning environment make student motivated or more satisfied from completing their studies. For that to happen, the individual institution must have proper educational utility infrastructure accumulated with academic and essential parameters of professional development. For example, students are more motivated, performer better, and become loyal to their universities if their institution has basic educational facilities with effective training and teaching staff. Improved student satisfaction, motivation, and impartiality directly depend on the teachers' performance outside and inside the classroom. Therefore, the students' evaluation of their course performance is related their instructors and methodology used in teaching. That also determines the students' successful completion and educational development of their studies because they believe that instructors with the highest intellectual ability as better teachers and reliable. We can deduce that students' satisfaction is largely dependent on quality standard. Teachers' reasonability, coordination, excellence, and ability are salient factors to be considered in ensuring standard for good higher institution. Since educational programs are coordinated for them by their instructors or teachers (Owston, York \& Murtha, 2013).

\section{Perceived Service Quality:-}

The perceived quality of service refers to the students' justification for the approach adopted in teaching quality by their lecturers and course instructors. For students to perceive the services as excellent, they must be of standardized output and better. Educational excellence in the universities depends on the service quality (Owston, York \& Murtha, 2013). Students also perceive the institutional service as being standardized and offered in a quality education environment if the University provide them with appropriate infrastructural and learning facilities and intellectual faculty to ensure they retain confidence and interest in the organization. Administrative and academic efficiency of the University, therefore, plays a major role in the motivation of the student. That happens through the institution's professional development, training and feedback for the student's mental development, transparency in the evaluation of the student, teachers' intellectual ability, and organizational harmony (Owston, York \& Murtha, 2013). 
The quality of the University service in education further encompasses medical facilities, security systems, updated and well-managed libraries, class facilitation and sitting arrangements and decoration coupled with multimedia as well as the cooperation of the administrative staff. Support services also contribute to their educational development and support (Owston, York \& Murtha, 2013).

In conclusion, we can say that both administrative and academic aspects of a University are significant in determining the students' performance, development of quality assurance and organizational image. Hence, the students' satisfaction is associated with the performance of a University's knowledge advisor, ability to get desired classes, instructor excellence, overall quality instruction, knowledgeable faculty, secure and safe campus, approachable advisor, worthwhile investment in paid tuition, availability of advisor, reasonable and clear requirements for major, unbiased and fair faculty, adequate computer labs, and access to information (Austin et al., 2014).

\section{Research Significance and Problem:-}

The significance of this research emerged from the importance of sustainable knowledge economy in which participation in providing quality standard education for higher education institution ensure student satisfaction thus enhance economic growth in the country (Coates, 2009), introduces continuous improvements to educational institutions' services, and adapts these improvements to achieve substantial improvements in service quality (Hafeez et al., 2011). The motivation for this study emanated from the administration of higher institution in UAE, which appropriate policies with regards to quality standard of the service rendered has been a major concern. Accordingly, the study problem can be demonstrated by answering the following questions and investigating the following hypotheses:

\section{Research Questions:-}

Q1: What is the relationship between oversight bodies and agencies determine teaching quality education on student satisfaction in higher education institutions of UAE.

Q2: To what extent has AACSB's Hiring Standards affected teacher Qualifications in higher education institutions of UAE

Q3: To what extent has university hiring standards affected teachers' qualification in higher education institutions of $\mathrm{UAE}$

Q4: What is the association between Teachers' qualification and presence of AACSB Hiring standard in higher education institutions of UAE

Q5: What is the relationship between Private Universities Hiring Standards and AACSB are not in ensuring student satisfaction in higher education institutions of UAE

Q6: To what extent has the five dimensions of service quality viz: assurance, empathy, responsiveness, tangibles, and reliability influenced students' satisfaction in higher education institutions of UAE.

\section{Research Hypotheses:-}

The hypothesis as per Turner (2015) is the most suitable guess a researcher can make based on the planned study.

The study's hypotheses are:

H1:There is no significant relationship between oversight bodies and agencies determine teaching quality education on student satisfaction in higher education institutions of UAE.

H2: AACSB's Hiring Standards does not have any significant impact on the teacher Qualifications in higher education institutions of UAE

H3: There is no significant effect of university hiring standards on teachers' qualification in higher education institutions of UAE

H4: Teacher qualification has no significant association to the presence of AACSB Hiring standard in higher education institutions of UAE

H5: Private Universities Hiring Standards and AACSB are not significantly related in ensuring student satisfaction in higher education institutions of UAE

H6: There is no significant linkage between students' satisfaction and the five dimensions of service quality viz: assurance, empathy, responsiveness, tangibles, and reliability in higher education institutions of UAE. 


\section{Methodology:-}

\section{Underpinning Theory for Quality Standard and Student Satisfaction:-}

The study adopted Herzberg's theory of job satisfaction to theorize the impact of quality standard in teaching process on student satisfaction in Private Higher Education Institutions in Dubai. In applying Herzberg's theory to this study, desired classes, instructor excellence, overall quality instruction, knowledgeable faculty, secure and safe campus, approachable advisor, worthwhile investment in paid tuition, availability of advisor, reasonable and clear requirements are directly related to the student satisfaction and may be considered motivators or satisfiers (e.g. growth and achievement).

While the absence of desired classes, instructor excellence, overall quality instruction, knowledgeable faculty, secure and safe campus, approachable advisor, worthwhile investment in paid tuition, availability of advisor, reasonable and clear requirements may lead to dissatisfaction, For example, fair and equable rules and polices are expected at a higher educational institution. It is only in the absence of fairness in availability of those salient factors that the student experiences dissatisfaction. The more, standard anddesired classes, instructor excellence, overall quality instruction, knowledgeable faculty, secure and safe campus, approachable advisor and availability of advisor, the higher the quality of standard rendered and thus, the increase in satisfaction of the students.

\section{Source of Data and Sample:-}

The chapter on collecting quantitative data is used for researching and analyzing questionnaires used to collect quantitative information. The questionnaires were distributed to 50 male and female students ofPrivate Universities in Dubai aged between 20 to 40 years. The coping strategies adopted and the questions asked strived to elicit participants' perspective regarding the quality of teaching in the university and subsequently, the impact it has on the students' level of satisfaction (Pickard, 2012). Specific questions were developed to establish the students' view purposely to enhance the situation. The selected respondents had diversified cultural and educational backgrounds since some of them came from foreign countries like Syria, Russia, Lebanon, Iran, Asia, Europe, India, and Emirates among others.

\section{Data Analysis Method:-}

The following methods and statistical indicators were used for statistical analysis and hypothesis testing:

1. Frequencies and percent for study sample distribution breakdown.

2. Means and standard deviations to indicate concentration levels or dispersion of sample responses regarding statements related to the application of service quality standards and student satisfaction.

3. T-test for independent variables to investigate whether there is a difference in the sample's attitudes toward service quality application in the universities and to ascertain the participants' attitudes toward their own satisfaction with university service quality (H1-H6).

4. Regression test to determine the effect of independent variables on dependent variables(H1-H5)

5. Reliability analysis to ensure the instrument reliability of Cronbach's alpha coefficient (H6)

\section{Findings and Discussion:-}

The survey established that $50 \%$ and above of the participants gained appropriate skills and knowledge at the university under study and that the teaching approach adopted by the institution was relevant to their expectations.

\section{Respondents' demographic profile:-}

Respondents' age:-

The researcher asked respondents to write their age limits when answering the questions asked in the questionnaire. The diagram below depicts the participants' response. 
Figure 4.2.1:- Respondents' age

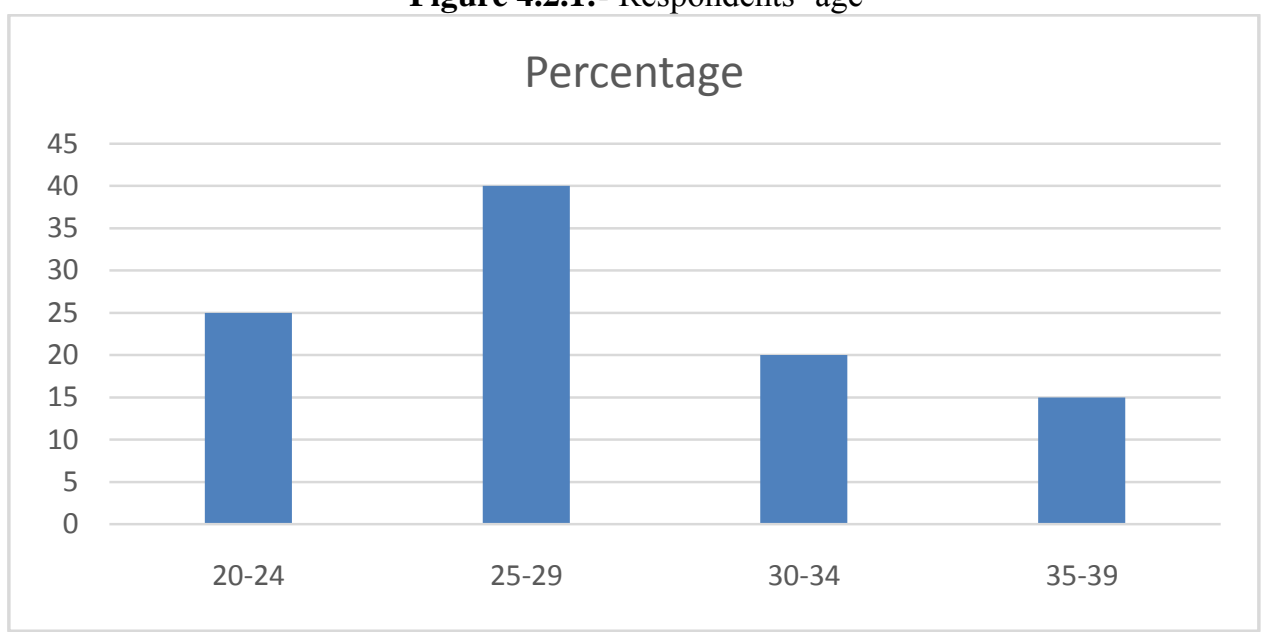

The figure indicates that $25 \%$ of the respondents were aged between $20-24$ years, $40 \%$ between $25-29$ years and $20 \%$ fell in the age bracket of 30 to 34 years. About $15 \%$ of the participants were aged between 35-39 years. The findings further established that a huge chunk of Private Universities students was below the age of 35 years constituting approximately $85 \%$ of the total student population. On the other hand, students aged above 35 years were less attracted to the institution since they were representation by $15 \%$ only.

\section{Distribution by gender:-}

The questionnaires also tasked respondents to show their gender when answering questions. The diagram below show what the outcome of the survey indicated.

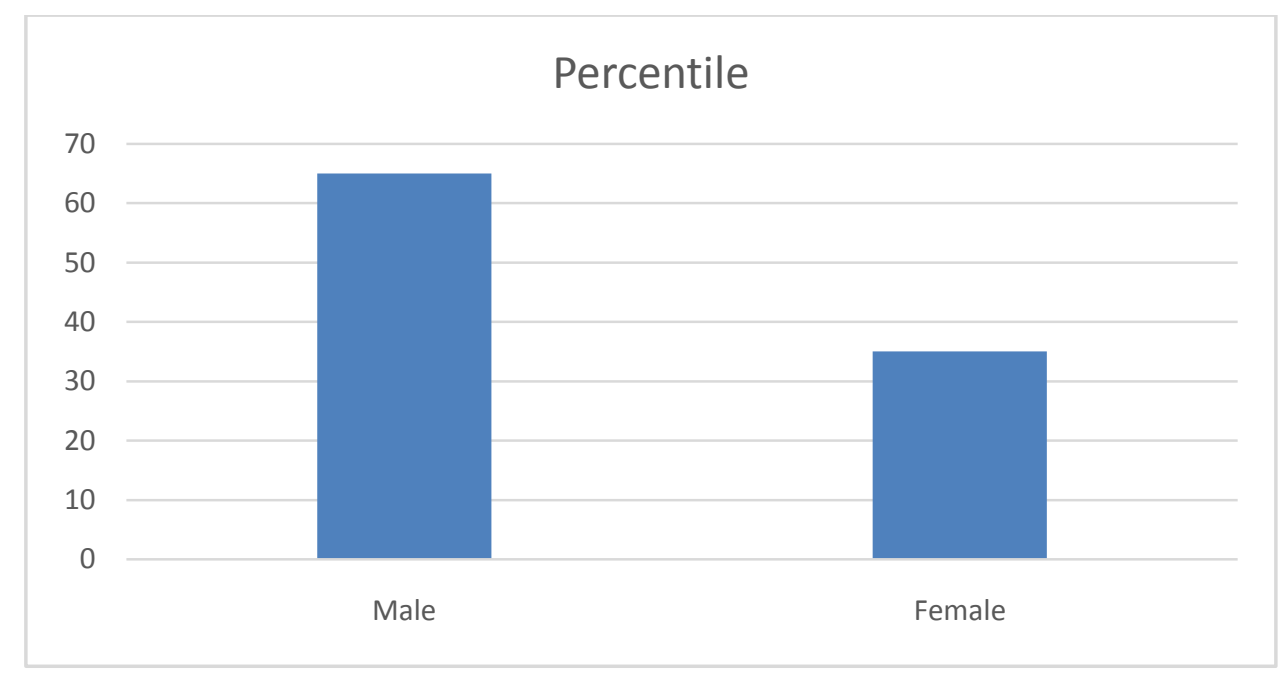

Figure 4.1.2:- Distribution by gender

The chart shows that male students represented $65^{\text {th }}$ percentile as opposed to the $35^{\text {th }}$ percentile of their female counterparts. The results indicate that the research was not gender-balanced because the variation between the male and female respondents was at 30 percentile. The big variance in gender representation is a further indicator that the student population at Private Universities was male dominated because the institution is science-oriented. Given that most female students detest studying science courses, it could be the reason for the huge variance in gender representation. 


\section{H2: Questionnaire Questions on the Determinants of Teaching Quality Education Teacher Education Accreditation:-}

AACSB-accreditation may the reason behind high standards of teaching at Private Universities and UAE in general. This is because AACSB has high-quality teaching standards it has established under which all universities and other institutions of higher learning prescribes to.

Table 4.2.1:- Relating Teacher Qualification and AACSB Accreditation

\begin{tabular}{|l|l|l|l|l|l|}
\hline Beta Coefficient & $\begin{array}{l}\text { \% of Teachers } \\
\text { that are well- } \\
\text { qualified }\end{array}$ & $\begin{array}{l}\text { \% of Teachers } \\
\text { who are well- } \\
\text { qualified in } \\
\text { English }\end{array}$ & $\begin{array}{l}\text { \% of Math } \\
\text { Teachers who } \\
\text { are well- } \\
\text { qualified }\end{array}$ & $\begin{array}{l}\text { \% of out-of-field } \\
\text { math teachers }\end{array}$ & $\begin{array}{l}\text { \% of out-of-field } \\
\text { English } \\
\text { Teachers }\end{array}$ \\
\hline $\begin{array}{l}\text { AACSB's } \\
\begin{array}{l}\text { Accredited } \\
\text { Universities }\end{array}\end{array}$ & $.43^{*}$ & $.48^{*}$ & $-.38^{*}$ & $-.38^{*}$ \\
\hline *P<.05 & $* * \mathrm{P}<.01$ & & & \\
\hline
\end{tabular}

The percentage of AACSB-accredited universities is negatively correlated at a significant level with that of out-0ffield math and English teachers. The reason may be due to the fact that AACSB-accredited universities must demonstrate high teaching standards in their respective fields particularly in science fields as per the case of Private Universities. There may be other institutional policies that may lead to quality teaching at Private Universities and other related institutions other that guidelines set by AACSB and subsequently supporting and leading to recruiting high-quality teachers.

As indicated in table 4.2.2, the extent to which university supervised by AACSB particularly Private Universities maintain high recruitment standards highly predict $(\mathrm{P}<.001)$ of the uncertified teachers' percentage. It as well indicates a strong correlation between fully certified teachers and new ones.

Table 4.2.2:- H2:Correlations between AACSB's Hiring Standards and Teacher Qualifications

\begin{tabular}{|l|l|}
\hline AACSB Hiring Standards \\
\hline$\%$ of Newly Certified Teachers & $.29^{* *}$ \\
\hline$\%$ of all newly certified teachers & $.32^{* *}$ \\
\hline$\%$ of uncertified newly certified teachers & $-.52^{* * *}$ \\
\hline$\%$ of all uncertified teachers & $-.65^{* * *}$ \\
\hline & \\
\hline
\end{tabular}

$* \mathrm{P}<.05 \quad * * \mathrm{P}<.01 \quad * * * \mathrm{P}<.001$

Table 4.2.3:- H3: Relationship between University Hiring Standards and Teacher Qualifications

\begin{tabular}{|l|l|l|l|l|}
\hline $\begin{array}{l}\text { Beta } \\
\text { Weight/Variable }\end{array}$ & $\begin{array}{l}\% \text { uncertified new } \\
\text { teachers }\end{array}$ & $\begin{array}{l}\% \text { uncertified all } \\
\text { teachers }\end{array}$ & $\begin{array}{l}\% \text { fully certified new } \\
\text { teachers }\end{array}$ & $\begin{array}{l}\text { \% full certified all } \\
\text { teachers }\end{array}$ \\
\hline $\begin{array}{l}\text { University hiring } \\
\text { standards**** }\end{array}$ & $-0.501(-3.18)^{* *}$ & $-0.637(-4.74)^{* * *}$ & $0.338(2.15)^{*}$ & $0.394(2.51)^{*}$ \\
\hline $\begin{array}{l}\text { Professional Board } \\
\text { Standards }\end{array}$ & $-0.081(-.49)$ & $-0.172(-1.72)$ & & \\
\hline $\begin{array}{l}\% \text { students in } \\
\text { poverty }\end{array}$ & $-0.107(-0.50)$ & $0.173(0.95)$ & $-0.062(-0.26)$ & $-0.147(-0.63)$ \\
\hline$\%$ LEP students & $0.046(0.24)$ & $0.106(0.64)$ & $0.375(2.03)$ & $0.227(1.24)$ \\
\hline$\%$ minority students & $-0.104(-0.41)$ & $-0.353(-1.67)$ & $-0.111(-0.42)$ & $0.124(0.57)$ \\
\hline
\end{tabular}

$* \mathrm{P}<.05 \quad * * \mathrm{P}<.01 \quad * * * \mathrm{P}<.001$

**** Is the percentage university teachers as a criteria for recruitment, graduation from an approved institution of education program, full certification, and a university minor or major degree certificate in the course to be taught.

The findings indicate that university teaching standards are both a local and state job. Taking a quasi-professional teaching scenario, we find a complex interplay between the procedures adopted by Private Universities and the standards set by AACSB sometimes in violation of and sometimes in accord with government or state requirements. 
AACSB enforce standards of teachers recruited in higher institutions. However, they do in an inviolable way to that of other professionals including lawyers and doctors. While other professionals embrace the use of professional standards boards established in UAE as the enforcement and standard-setting body. Based on the level of autonomy and authority used to measure the characteristics, UAE has bodies mandated to manage and administer teaching standards in the region.

As indicated in table 4.2.4, there is a significant relationship between AACSB's recruitment standards and teacher qualification. In table 4.2.5, there is a huge relationship between uncertified and certified teachers and the establishment of AACSB. Therefore, the connection between the two is working because of the pressure the university is getting from AACSB to employ qualified teachers.

Sometimes universities and other institutions of higher learning recruit uncertified teachers due to bureaucratic and cumbersome hiring procedures, efforts to minimize salary costs, lack of recruitment incentives or effort, or patronage. AACSB has the power and authority to ensure all universities including Private Universities recruit certified and qualified teachers to ensure teaching quality education.

Table 4.2.4:- H4; Correlations (Pearson r) of Teacher Qualification and Presence of AACSB

\begin{tabular}{|l|l|}
\hline $\begin{array}{l}\text { \% universities demanding graduation from accredited } \\
\text { teacher education institutions }\end{array}$ & $0.26^{*}$ \\
\hline $\begin{array}{l}\% \text { of Universities demanding a minor or major degree in } \\
\text { the course to be taught }\end{array}$ & $.31^{* *}$ \\
\hline$\%$ uncertified teachers & $-.26^{*}$ \\
\hline$\%$ fully certified teachers & $.20^{*}$ \\
\hline$\%$ new fully certified teachers & $.22^{*}$ \\
\hline Weeks needed for teaching students & $.24^{*}$ \\
\hline
\end{tabular}

$* \mathrm{P}<.05 \quad * * \mathrm{P}<.01$

Table 4.2.5:- H5:Relationship between Private Universities Hiring Standards and AACSB

\begin{tabular}{|l|l|}
\hline & Private Universities Hiring Standards \\
\hline AACSB & $.412(2.50)^{* *}$ \\
\hline$\%$ Poor Students & $.131(.57)$ \\
\hline \% Students LEP & $-.428(-2.19)^{*}$ \\
\hline Minority Students & $.068(.27)$ \\
\hline & \\
\hline
\end{tabular}

$* \mathrm{P}<.05 \quad * * \mathrm{P}<.01$

The link between AACSB and teacher hiring practices or education may be very important but are somehow modest (correlations ranging 0.2 to 0.3 ). This indicates that there are other factors contributing to teaching quality education in higher institutions of learning and Universities in Dubai in particular. It is a fact that Private Universities are in position and does develop and implement high teaching standards without being pressured by AACSB. AACSB's existence has led to high recruitment standards of teachers at Private Universities and in the UAE's education sector in general.

\section{Effects of Teaching Quality Education in the Universities:- Data Collection and Research Instruments:-}

Five dimensions of quality teaching were adopted in this study including (assurance, tangibility, reliability, empathy, and responsiveness). These elements were subsequently used in five points Likert scale whereby 5 strongly agree and 1 strongly disagree. Respondents, like I said, were randomly sampled.

\section{Reliability Test:-}

Reliability test strives to yield consistent results through free measure. This indicates the consistency and stability with which the instrument used in the exercise measures the worthiness of the adopted measure. The coefficient reliability that is close to 1.0 indicates the measure is better while those close to 0.80 are good. Acceptable values fall within 0.70 while those within 0.60 and below are poor. The researcher used Cronbach's alpha reliability analysis method to test all the constructs for consistency reliability. The used values are as put in the table below. 
Participants' confidentiality was also assured. The findings indicated that all the constructs exceeded the 0.70 thresholds meaning the constructs' scales of measurement used in the study were consistent and stable (Pedhazur\&Schmelkin, 2013).

Table 4.3.2:- H6: Reliability Test based on Cronbach's Alpha

\begin{tabular}{|c|c|c|}
\hline Construct & Number of Items & Alpha \\
\hline Customer Satisfaction & 50 & .874 \\
\hline Empathy & 40 & .732 \\
\hline Tangibles & 45 & .848 \\
\hline Reliability & 40 & .756 \\
\hline Responsiveness & 40 & 732 \\
\hline Assurance & 50 & .829 \\
\hline
\end{tabular}

\section{Pearson Correlation Coefficient:-}

Pearson's correlation coefficient (r) measures the relationship between two research variables. Besides Standard and mean deviations between independent and dependent variables, the researcher further strives to establish the closeness between one variable to the others. The strength of association or correlation between the dependent and independent variables is required in any study (Pedhazur\&Schmelkin, 2013).

In this case, the researcher wants to know the significance of the correlation between the identified variables. Correlations may vary from 1.0 to +1.0 . Regarding information, the acceptable conventional level is significant of $\mathrm{p}=.5$ in any social study like this one. A true significant variable correlation is between 95 times out of 100 (Pedhazur\&Schmelkin, 2013). This indicates that 95 times out because it would mean that the researcher's findings are only 5\% unreliable. According to our mean values, students' satisfaction is based on the five dimensions, assurance, empathy, responsiveness, tangibles, and reliability. If the universities are offering education that is at their expectations, they are likely to be satisfied. If the education is beyond their expectations, they will be very satisfied. Alternatively, the students will be extremely satisfied if they are offered education that is more than their expectations.

\begin{tabular}{|c|c|c|c|c|}
\hline Variables & \multicolumn{2}{|c|}{ International Students } & \multicolumn{2}{c|}{ Local Students } \\
\hline & Mean & SD & Mean & SD \\
\hline Student Satisfaction & 4.13 & 1.01 & 4.26 & 1.03 \\
\hline Empathy & 3.29 & .712 & 3.48 & .732 \\
\hline Tangibles & 3.32 & .734 & 3.36 & .724 \\
\hline Reliability & 3.44 & .862 & 3.42 & .882 \\
\hline Responsiveness & 3.49 & .704 & 3.44 & .734 \\
\hline Assurance & 3.76 & .717 & 3.32 & .727 \\
\hline
\end{tabular}

Pearson Correlation was used in this research. Results for empathy indicate that international students' mean is 3.29 while that of their local counterparts is 3.48. This shows that private universities students confirm that the institution offers empathy education service and was more satisfied as opposed to their international counterparts. Tangibility mean at 3.36 for local students and 3.32 for international ones indicate that the local students are more satisfied with the university's tangible service. Reliability mean for local students is 3.43 while for international ones is 3.44 . This shows that international students at Private Universities were more satisfied compared to their local counterparts because they believe the institution is offering reliable service. The responsiveness of the local students is 3.44 while for the international students is 3.49. This means regarding the institution's ability to offer responsive services, the international students are more satisfied as opposed to their local counterparts. About assurance, the local Private Universitiesstudents are 3.32 while that of international ones is 3.76 indicating international learners were more satisfied with the service assurance of the university.

\section{Conclusion:-}

The study strived to explore teaching quality education in higher institutions of learning particularly at Private Universities. The research indicated that the student's satisfaction level is dependent on many aspects including the learning environment and the quality of teaching at the University. Students want institutions where there are well experienced, learned, and qualified faculty to cater for their professional and academic needs. They want teachers with reasonability, liberty, expertise, and knowledge that is up to the mark. The teachers' teaching attitude must also 
be friendly and the methodology of executing the task and course appropriate. The institution must also have a good learning environment and be well equipped to guarantee an excellent education. The student's security and access to information among other elements fundamentally determine their level of satisfaction in the Universities as well.

Private Universities is a Center for excellence given that it offers courses that are in high demand in the labor market. The institution is well facilitated both by infrastructure and staff service. Students at Private Universities have high satisfaction levels because the institution offers courses that impact on the students with right skills and knowledge. However, the university's IT infrastructure underdeveloped hence the need to invest more resources in upgrading the system. By doing so, the institution will attract students from the region and other parts of the world.

The study recommends policy to enhance high quality standards in the Teaching Process in Higher Education Institutions such that managers and administrative executives should consider enhancing the academic and institutional status the University with regard to the highlighted determinants of teaching quality education as well as the different student dimensions of quality perception. They should adhere to the requirements, standards, and necessities of quality education based on the students' demand. That includes ensuring the university has reliable facilities as well have the administrative staff ability to have empathy among other factors mentioned in the discussion.

\section{References:-}

1. Ahmad, S. Z., \& Hussain, M. (2015). An investigation of the factors determining student destination choice for higher education in the United Arab Emirates. Studies in Higher Education, 1-20.

2. Austin, A. E., Chapman, D. W., Farah, S., Wilson, E., \& Ridge, N. (2014). Expatriate academic staff in the United Arab Emirates: the nature of their work experiences in higher education institutions. Higher Education, 68(4), 541-557.

3. Baker, F. S. (2015). Developing Teachers and Children for Inclusive Educational Practices in Abu Dhabi, United Arab Emirates. Childhood Education, 91(4), 283-291.

4. Bamber, V. (2012). A Holistic Approach to Achieve Quality in Higher Education.

5. Gaad, E., Arif, M., \& Scott, F. (2006). Systems analysis of the UAE education system. International Journal of Educational Management, 20(4), 291-303.

6. Green, D. (2014). What is quality in higher education?.

7. Meyer, K. A. (2014). Quality in Distance Education: Focus on On-Line Learning. ASHE-ERIC Higher Education Report. Jossey-Bass Higher and Adult Education Series.

8. Mullen, C. A., Samier, E. A., Brindley, S., English, F. W., \&Carr, N. K. (2013). An epistemic frame analysis of neoliberal culture and politics in the US, UK, and the UAE. Interchange, 43(3), 187-228.

9. Nightingale, P., \& O'Neil, M. (Eds.). (2012). Achieving quality learning in higher education. Routledge.

10. Owston, R., York, D., \& Murtha, S. (2013). Student perceptions and achievement in a university blended learning strategic initiative. The Internet and Higher Education, 18, 38-46.

11. Pickard, A. (2012). Research methods in information. Facet publishing.

12. Turner, D. (2015). Research hypothesis of the study. Cognitive Psychology.

13. Wilkins, S., Stephens Balakrishnan, M., \& Huisman, J. (2012). Student satisfaction and student perceptions of quality at international branch campuses in the United Arab Emirates. Journal of Higher Education Policy and Management, 34(5), 543-556.

14. Witte, S. (2015). Gulf State branch campuses: Global student recruitment. International Higher Education, (58).

15. Zahran, R., Pettaway, L. D., \& Waller, S. (2016). Educational Leadership: Challenges in United Arab Emirates. Educational Leadership, 5(1).

16. Pedhazur, E. J., \&Schmelkin, L. P. (2013). Measurement, design, and analysis: An integrated approach. Psychology Press1.2 Introduction to the Subject Area 